\title{
Diffusion of sustainability reporting in universities: Current situation and future perspectives
}

\section{Introduction}

During the past decade, companies worldwide have adopted sustainability reporting (SR) in response to stakeholders' demands and in an effort to legitimize their business strategies, particularly in light of the on-going financial crisis (Lozano and Huisingh, 2011; Alonso-Almeida et al., 2012; Lozano, 2013). Primary stakeholders are examining business activities in detail and are demanding more reliable information to evaluate firms (PradoLorenzo et al., 2009).

The Global Reporting Initiative (GRI) produces the most widely used global standards for sustainability reporting worldwide (e.g., Prado-Lorenzo et al., 2009; Tsang et al., 2009; Brown et al., 2009; Levy et al., 2010; Marimon et al., 2012). Research on the diffusion of the GRI reporting standards has shown that companies with greater visibility and levels of pollution are the pioneers in the voluntary, open disclosure of company data (Outtes Wanderley et al., 2008; Alonso-Almeida et al., 2012).

Society is increasingly sensitive about issues related to sustainable development (SD) (Lozano et al., 2013) and no doubt that the university contributes to explaining the phenomenon (Ferrer-Balas et al., 2010). Thus, society is beginning to demand information from other organisations, such as public agencies and universities. Universities, in particular, play a key role in society by preparing future graduates who will manage companies and other organisations, create new companies and become future leaders (Cornelius et al., 2007; Waples et al., 2009). In light of the world's complex challenges, universities have a twofold mission: provide students with new competences to create a more sustainable society (Carol et al. 2011) and reduce the environmental impact of their operations (Disterheft et al., 2012). In this way, SR provides a useful means of communicating universities' efforts and sustainable progress to the university community (Lozano, 2011). Nevertheless, as this author suggests, the diffusion 
of SR among universities is in an early stage, and more research is required to elucidate what SD entails and to promote SR in universities.

To address this research gap, this exploratory work uses a combination of qualitative and quantitative methods to achieve three main objectives. First, at the macro level, regressions of temporal series of available data adjusted to logistic curves are used to explain and predict the diffusion of the GRI reporting standards in universities on a global scale. Second, a descriptive analysis of the diffusion of the GRI reporting standards is used to describe different patterns regarding the current use of reporting standards. Finally, two case studied are analysed to identify the dimensions of SD and SR in the diffusion of the GRI reporting standards. This study focuses on the GRI reporting standards because they are the most prevalent standards for sustainability reporting and, after ISO 14001, are the most influential reporting standards with regard to social responsibility (Berman et al., 2003).

This study contributes to the extant research in three ways. First, it increases the understanding of the diffusion of SR in universities. Second, this research provides an exploratory descriptive analysis of the diffusion of the GRI reporting standards worldwide by analysing data on universities on both the macro and micro level. Finally, it identifies future trends in the diffusion of the GRI reporting standards in universities.

The remainder of the paper is organised as follows. First, a framework for SD in universities and a model for studying SD in universities are presented. The methodology and data analysis are then explained, including a presentation and analysis of the case studies. Next, a section is devoted to the study's results. Finally, the conclusions are presented, along with a discussion of the study's limitations and suggestions for future lines of research.

\section{Framework for Sustainable Development in Universities}

The most accepted definition of SD is contained in the document "Our Common Future", by the World Commission on Environment and Development: "Sustainable development is the development that meets the needs of the present without compromising the 
ability of future generations to meet their own needs" (WCED, 1987: 37). Over time, a vast body of literature has emerged that has addressed different aspects of this concept.

In the field of education, the concept of "education for sustainable development (ESD)" was established at the Summit on SD held in Johannesburg, South Africa, in 2002. In December of the same year, the United Nations General Assembly adopted a resolution to establish a United Nations Decade of EDS, spanning from 2005 to 2014. During this period of time and after multiple conferences, great efforts have been made to transform traditional environmental education into EDS (Jickling and Wals, 2008).

Since 2002, many higher education institutions have joined this process of disseminating sustainability principles, but there is still much progress to be made. Owing to their institutional relevance, universities are well placed to deliver the message of SD to a wide audience (Filho, 2010). Universities, which aim to educate and prepare future decision makers, play a key role in creating new mental paradigms related to sustainability. Several initiatives are contributing to the development of the sustainability science through the collaboration of several prestigious universities, such as Alliance for Global Sustainability, Integrated Research for Science Sustainability and the International Network for Sustainability Science (Yarime et al. 2012).

Various national and international declarations concerning sustainable development in higher education have been developed over time, and numerous universities all over the world have signed them. The most important of these declarations have been the declarations of Tiblisi, Tailloires, Halifax, and Lünemburg as well as the COPERNICUS charter (Wright, 2004). More recently, at the UN Conference on SD in 2012, known as Rio +20, the commitment of higher education institutions to the development of sustainable practices was discussed, and a Declaration ${ }^{1}$, to be signed voluntarily by universities, was drafted. By signing the Declaration,

\footnotetext{
${ }^{1} \mathrm{http}: / /$ www.uncsd2012.org/index.php?page=view\&nr=341\&type=12\&menu=35 Accessed September 13, 2013.
} 
an institution commits to teach concepts related to SD, encourage research on development issues, support sustainability efforts and engage with and share its results through international SR frameworks.

As shown in Figure 1, higher education institutions promote SD by transforming their own missions, restructuring their curricula, modifying their research programs, introducing new ways to live on their campuses, promoting community engagement and outreach (Wals, 2013) and, finally, assessing and reporting these activities to stakeholders.

Figure 1. Model for sustainable development in universities

\subsection{Sustainable Development in Universities}

The Global University Networks for Innovation has published a series of research compilations on the social commitment of universities (GUNI 2014, 2012, 2008). The reports examine the sustainability activities in various regions and geographical areas and identify the main barriers that universities face in contributing to the sustainability paradigm. The report shows that sustainable development in higher education institutions requires not only making statements and preparing documents but also taking concrete actions.

Regarding institutions' curricula and competences, ESD seeks to shift the focus on both teaching and learning processes by integrating principles, values and practices related to SD. Although an increasing number of universities are incorporating topics related to SD into their curricula, teaching students about sustainability is considered to be a difficult task. Lozano (2010) analysed 5,800 course descriptions from 19 of the 28 schools at Cardiff University and concluded that to better incorporate SD into education curricula, a more balanced, holistic and trans-disciplinary approach is needed. In this regard, the Sustainability Tool for Assessing Sustainability in UNiversities' Curricula Holistically (STAUNCH®) has 
been used for the Bachelor and Master programmes in the Faculty of Business and the Faculty of Environment at the University of Leeds (Lozano and Young, 2013) as well as to assess the School of Chemistry at Cardiff University (Lozano and Watson, 2013). The challenge is to integrate concepts related to SD into all the courses, not merely those courses related to SD, such as environmental studies or engineering. From a different perspective, the work of Murga Menoyo (2008) aimed to identify the needs of students regarding sustainability to design an appropriate study program for them.

Sustainability has become a multidisciplinary scientific field. To recent years, this research field has developed different methodological approaches and diverse research techniques from a wide variety of disciplines, such as environmental science, sociology, ethics, economics and politics (Filho, 2011). According to the Statement of the Worlds' Scientific Academies, the contribution of science and technology to the transition to sustainable development must be significantly strengthened by (1) sustaining long-term basic research and linking it to societal goals; (2) globally coupling or pairing national and local institutions in conducting effective research into systems; (3) linking academia, government and the private sector in collaborative research partnerships and (4) integrating disciplinary knowledge into interdisciplinary, locally focused, problem-driven research and application efforts (Hassan, 2001).

In a large number of higher education institutions, campus greening initiatives are changing the way that some operations are performed in order to integrate sustainable development into regular university life. University campuses are like small cities, and some of them are taking concepts related to sustainable development into account. Universities play an important role in this realm. The main areas that require improvement are related to the environment, the efficient use of resources, and the reduction and treatment of waste (Wright and Wilton, 2012). Broadly, sustainability projects can range from very specific actions to large ones (for instance, from the issue of an environmental evaluation system for the management of a university restaurant (Nilsson et al., 1998), to the analysis of the carbon footprint of a 
university (Larsen et al., 2013). Some efforts have also been made, such as in Malaysia, to develop tools to assess the level of SD in university campuses (Saadatian et al., 2013).

Moreover, in many universities and academic publications, the university's contribution to the social and economic development of the community is identified as engagement or outreach. In practice, these two concepts are used interchangeably and include many potential activities. In identifying three characteristics of engagement, the Committee on Engagement (2005) of the Committee on International Cooperation (CIC) stated that engagement (1) is scholarly, involving both the act of bringing communities and universities together and the product of the collaboration; (2) overlaps with the three missions of the university and thus is not performed separately from education, research and service; and (3) is reciprocal and mutually beneficial for the university and the community.

When this function becomes more important with regard to the responsibilities of a university, major efforts are made to document and communicate the university's activities in this area. The documentation of engaged scholarship plays an important role in the alignment of the teaching staff's objectives with the institution (Moore and Ward, 2008). Michigan State University has developed a faculty survey instrument, the Outreach Measurement Instrument, to gather information on the entire institution regarding outreach activities (Church et al., 2003).

Universities can legitimize their efforts by reporting their activities toward sustainability (Alonso-Almeida et al., 2012). There are three main purposes for sustainability reporting: (1) to assess $\mathrm{SD},(2)$ to communicate sustainability efforts and progress and (3) to develop a tool for analysis among universities (Lozano, 2011; Lozano and Huisigh, 2011). Therefore, SR should provide information for all stakeholders (Moneva and Martin, 2012) and could encourage SD comparisons among universities and benchmarking activities (Lozano, 2006).” 
Last, Barth et al. (2012) performed a scenario analysis to examine possible future developments of SD in higher education. The results provide a "Higher Education Landscape 2035", characterised by three clusters of institutions and eight possible scenarios. These clusters contain three types of clearly differentiated universities: universities with a principally close orientation to society (open-to-life universities that act as a financially strong cooperative partner), universities that are rather distant from society (conservative universities that maintains a niche existence), and universities with a predominantly instrumental role (marketoriented universities that generate profitable knowledge).

\subsection{Global Reporting Initiative and Universities}

During the last decade, through SR, companies have provided relevant information for stakeholders to assess their strategies, operations and future plans in a manner that extends beyond what is provided in their financial reports (Krajnc and Glavi, 2005; Gilbert and Rasche, 2007). The increase in SR growth has been evident in all sectors (Alonso-Almeida et al., 2012) worldwide (Marimon et al., 2012). Nevertheless, SR is still rare in universities (Lozano, 2011).

According to a number of researchers (e.g., Tsang et al., 2009; Brown et al., 2009; Levy et al., 2010; Lozano, 2011; Marimon et al., 2012), the GRI reporting standards are the most widely used and best available standards for SR worldwide because they consider economic, environmental and social dimensions and have developed specific sector-related guidelines (Manetti, 2011; Alonso-Almeida et al., 2012). Guidelines are not available yet in all sectors, and some SR are not as completed as expected (Lozano and Huising, 2011). In particular, the financial services and energy sectors are the main pioneering sectors, although other sectors have advanced in recent years in an effort to be more sustainable and to construct a new identity defined by legitimate behaviours and an improved image (Alonso-Almeida et al., 2012). Lukman et al. (2009) asserted that most European universities still do not engage in SR. Carol and Petrella (2010) noted that few universities disclose their GRI sustainability reports. Later, 
Disterheft et al. (2012) indicated that although the implementation of SR policies is increasing in European universities, SR is not yet a common practice. Other authors also reported a growing importance of SR among university stakeholders, such as faculty staff, alumni and parents (see Fonseca et al., 2011 in Canada and Yuan et al. 2013 in China).

Although universities often disclose their SD activities, the diffusion of SR is still in an early stage. One possible explanation is that universities continue to be very traditional (Lozano et al., 2013). Thus, SR could be considered as an innovation in universities (Barreto and Kemp, 2008). The diffusion of innovation usually starts slowly, and after an expansion stage, a level near its saturation is reached (Nill, 2008; Marimon et al., 2011). Consequently, the diffusion of SR is still in its infancy in universities. Hence, according to the aforementioned research, this study's main propositions are as follows:

Proposition 1: The adoption of GRI reporting standards in universities is in an early stage worldwide.

Proposition 2: Universities that have already adopted GRI reporting standards could be considered innovators.

Two other issues relevant to understand the diffusion of SR in universities are geographical diffusion and disclosed data.

In the context of geographical diffusion, the fastest adoption processes can be explained as a contagion or mimetic effect $(\mathrm{Nill}, 2008)$ encouraged by internal or external pressures from relevant stakeholders, regulations and the need for improved visibility or reputation (Qi et al., 2011; Marimon et al., 2012). The business adoption of the GRI reporting standards is highest in Europe, followed by Asia and Latin America (Marimon et al., 2012).

Regarding the data that are disclosed, university systems differ from traditional companies, but like other organisations, universities appear to be making efforts in SD in education and in campus operations, as mentioned in the previous section (Waas et al., 2012). On the one hand, some measures are used to reduce energy and water consumption, such as paper and waste recycling, and to encourage certain practices, such as the use of bicycles and 
solar systems on campus (Shriberg, 2002; Arvidsson, 2004; Lozano, 2011; Moneva and Martin, 2012). On the other hand, education curricula and teaching have included environmental courses in bachelor's and master's programs (Matten and Moon, 2004; Lozano, 2010; Waas et al., 2012).

Consistent with this information, Lozano (2011) analysed the type of data that are disclosed through SR under the GRI reporting standards and found that universities primarily disclosed economic and environmental data, whereas the intensity of data disclosure concerning the social dimension depended on the human resource policies of each university. Moneva and Martin (2012) found similar results in Spanish universities. Nevertheless, data on all SD dimensions should be demanded, as Figure 1 shows. Thus, the following propositions are suggested:

Proposition 3: The diffusion of GRI reporting standards in universities shows the same geographical pattern as the general diffusion of the GRI reporting standards.

Proposition 4: Data disclosed through SR are disclosed according to the model proposed in Figure 1 (specific for universities).

\section{Methods}

The analysis was conducted in three steps, as noted previously. At the macro level, GRI (2012) data were regressed using a logistic curve. Next, a descriptive microanalysis was performed, and last, a deep qualitative analysis of two SR data (École Polytechnique Fédérale de Laussane and La Trobe University) was used to shed light on the exploratory analysis.

As mentioned previously, the first step in the analysis was to adjust the historic GRI data to logistic curves. A stream of literature has studied the diffusion of management standards through the application of logistic curves (e.g., Barreto and Kemp, 2008; Nill, 2008; Marimon et al., 2012). Roger (1962) was one of the pioneers in investigating the diffusion phenomenon, referred to as innovation. According to Rogers, diffusion is the process that explains how innovation is spread through certain channels over time within certain populations of potential adopters. Since then, it has been common to use the terminology that he suggested for the 
different adopters of innovation, depending on when they adopt the innovation. Once all data on adopters over time are recorded, "Innovators", the first $2.5 \%$ to adopt, are differentiated. Other groups are labelled "early adopters", the "late majority" and "laggards", depending on when they adopt the innovation.

An "S"-shaped curve describes this phenomenon. It is also observed that the growth rate during the first stages is higher than that observed when the laggards adopt. At the end of the diffusion process, growth slows down, eventually resulting in an asymptotic pattern over time when the diffusion reaches saturation. The model is expressed in equation 1:

Equation 1: Logistic function

$$
N=\frac{N_{0} K}{\left(K-N_{0}\right) e^{-r_{0} t}+N_{0}}
$$

$\mathrm{N}$ represents the number of individuals in a population as a function of time. When the pattern is applied to analyse the diffusion of a management standard, $\mathrm{N}$ is the number of certifications at a certain moment. $\mathrm{N}_{0}$ represents the number of individuals at the starting point. Again, in the case of the diffusion of a management standard, this variable is the number of certifications during the year that the standard is established. $\mathrm{K}$ is the maximum level that can be reached, i.e., the saturation level. It is implicit in the model that such a level will never be reached. For practical reasons, it is quite common to use $95 \%$ of this saturation rate to estimate the time at which the phenomenon will stagnate. The initial growth rate is determined by $\mathrm{r}_{0}$, and the independent variable, time, is represented by $\mathrm{t}$.

This model has been used successfully by academics to explain the diffusion of the ISO 9001 standard (i.e., Marimon et al., 2006, Franceschini et al., 2010, Llach et al., 2011 and Sampaio et al., 2011). This model has been applied to other quality management standards as well, such as the "Q" standard for the tourism sector in Spain (Casadesus et al. 2010, AlonsoAlmeida et al. 2013). On the basis of the aforementioned work, Marimon et al. (2004, 2006, 2009 and 2010) described the ways in which the logistic model is also applicable to the diffusion of environmental management systems, particularly the ISO 14000 standard. The 
pattern explains the diffusion of the GRI reporting standards by country and sector (Marimon et al. 2012; Alonso-Almeida et al., 2012).

\section{Results}

The first results shown in this section are some regressions adjusting the logistic pattern to the available GRI data. Next, a descriptive analysis provides general comments about the diffusion of SR in geographical areas, and finally, a deep analysis of the two cases is presented.

The data provided by GRI (2012) have been adjusted to logistic curves for similar service sectors and universities. Each GRI SR has been taken as a unit in our analysis, although some universities present several GRI SR at the same time. Figure 2 shows the logistic curve regression for "Non-profit services", "Public Agencies" and "Healthcare Services". The pattern fits, showing a very high $\mathrm{r}$ squared value. The 95\% saturation rates are relatively low, ranging between 234 and 309. In two of the three cases (Non-profit services and Public Agencies), the number of certifications in 2012 was quite high, at approximately $80 \%$ of the saturation level, and thus, both sectors are close to entering the "laggards" stage of the "S" curve, which, in both cases, will be reached in 2016. In the case of Healthcare services, the number of certifications had not yet reached $50 \%$ of the saturation level in 2012 , and it is expected that the sector will reach 95\% saturation in 2019. These three sectors were analysed because they could be considered to be similar to universities, and therefore, universities may show the same level of diffusion.

Figure 3 focuses on the university sector. The estimation of the number of universities that will adopt the GRI reporting standards is slightly above 300 . Considering the vast number of universities around the world, the estimated diffusion of GRI reporting standards is irrelevant. The same can be said for the three previous sectors that were analysed. Figure 2 provides some insight into the findings. First, universities are in the first stages of the logistic curve. Only $22 \%$ saturation has been reached in terms of the number of universities that were 
certified before 2012 . The $95 \%$ saturation rate is expected to be reached in 2022 . Therefore, as proposed, the diffusion of SR in universities is in an early stage. Some additional arguments must be made to universities to convince them of the benefits that the GRI reporting standards provide; otherwise, the diffusion of SR in universities will remain low. Moreover, given the level of saturation achieved, universities could be considered early adopters and not innovators.

Figure 2. Evolution and forecast of diffusion of SR in public industries through a logistic curve.

Figure 3. Evolution and forecast of diffusion of SR in universities through a logistic curve.

To proceed to the descriptive analysis, table 1 provides a historic summary of universities' adoption of GRI reporting standards and their main characteristics As observed, Europe is the leading continent in adopting the GRI reporting standards, with $55 \%$ of all universities adopting the GRI reporting standards. North America ranks second, with 19\% of all universities adopting the GRI reporting standards, and Latin America ranks third, with 13\%. Asia ranks fourth, along with Oceania. This finding differs regarding the general diffusion founded by Marimon et al. (2012) where Asia ranks in second place.

Regarding the application level, only $59 \%$ of the universities reported their application level in their SR data, among which $26 \%$ are level A or expert and $37 \%$ are level B or intermediate and level C or introductory. Moreover, a "+" is added when sustainability reports are audited by a third party. In the case of universities, only six GRI sustainability reports have a "+" for three universities. Therefore, it seems clear that there is room for improvement with respect to SR in universities.

The main differences found between universities and other industries in terms of the adoption of the GRI reporting standards are as follows: 1) adoption is later in universities than in companies; 2) the level of adoption is lower among universities than among companies, with 
universities adopting the GRI reporting standards in only 18 countries; and 3) disclosure is less consistent in universities than in companies. While companies publish one report per year, only $8 \%$ of the universities have disclosed three consecutive reports (one per year), and only $33 \%$ disclosed one report during the period analysed.

There are several guidelines for SR. One that deserves special interest, considering its scope and its configuration in the university network, is Sustainability4U, which a cooperative initiative among four universities in Graz (Austria) (Universität Graz, Medizinische Universität, Kunstuniversität, and Technische Universität) that was established in 2009. It should be mentioned that Universität Graz has used the GRI guidelines since 2005.

Table 1. GRI Sustainability Disclosure Database-Universities

The last step of the analysis consisted in a qualitative study of the two aforementioned universities, one in Switzerland and another in Australia. The profile, mission, geographical area and other features differ between these universities, and thus, these two universities provide good examples of different approaches to SR in the university sector.

In our analysis of the sustainability reports included in GRI database, we considered sustainability reports to be "organizational documents" (as Bryman and Bell, 2007: 566, recommend) that can shed light on certain aspects of an organisation's behaviour. Following Scott's advice, sustainability reports were checked against Scott's (1990: 6) four criteria: authenticity, credibility, representativeness, and meaning. The reports can be considered genuine and of unquestionable origin (authenticity), considering the GRI's previous assessment of the reports. We have not analysed each document in the database to determine whether all the reports are free of errors and distortion (credibility); the only evidence regarding the credibility of the reports came from the GRI screening (and, in some cases, from third-party audits). The level of application depends on the expertise of the organizations, in our case universities, which are labelled by GRI as expert (A), introductory (C) or intermediate (B) 
depending on the amount of disclosures covered in the report. The categorization for our selected cases has been proposed by the universities and checked by GRI (GRI, 2014).

The reports that were studied (especially, those from La Trobe University and EPFL) show the sustainability activities that were deployed. Finally, the reports that were studied provide comprehensible and clear evidence regarding the universities' efforts toward sustainability.

The École Polytechnique Fédérale de Laussane is one of two Swiss Federal Polytechnical Universities. The EPFL Sustainability Report 2010-11 is a GRI report that follows the GRI-G3 2006 guidelines (which establish how to report and what should be reported) with a B application level. It is a GRI report that follows a multi-source sustainability framework. In this case, the sustainability efforts are based on the ISCN-GULF Sustainable Campus Charter. ISCN stands for International Sustainable Campus Network (www.iscnetwork.org), and GULF stands for Global University Leaders Forum. GULF, of which 25 university heads are members, was fostered by the World Economic Forum. EPFL reports under the ISCN-GULF Sustainable Campus Charter follow the GRI guidelines.

EPFL is also committed to continuous improvement in its reporting and indicator levels, as shown in the 2010-11 report. An advanced orientation towards the inclusion of indicators focused on curricula, research, and service is also found in EPFL reports. EPFL attempts to raise awareness of social and environmental issues among students through the inclusion of human and social science matters in its technical curriculum (EPFL, 2012: 27).

At EPFL, as a starting point, promoting SD calls for a transformation of the university's mission. In applying the third ISCN-GULF (International Sustainable Campus Network, Global University Leaders Forum) principle, EPFL explains that “to align the organisation's core mission with sustainable development, facilities, research, and education should be linked to create a 'living laboratory' for sustainability" (EPFL 2012: 15). The application of this principle implies that EPFL is committed to curriculum greening (e.g., within the ENAC Program, 168 Master's degree students were offered 15 lectures devoted to sustainable 
development), research on sustainability issues (the design and construction of the Solar Park Romande-Energie EPFL), campus greening (e.g., A Power Grid on a Chip, designed to manage power grids in several EPFL buildings), and engagement and outreach (e.g., the OpenSense project, devoted to improving the efficiency of public transport networks using mobile phone networks.).

La Trobe University (LTU) is a multi-campus university located in Victoria, Australia. LTUs' sustainability reports are based on the GRI G3.1 Sustainability Reporting Guidelines. The G3.1 Guidelines are an extension of the basic GRI framework that is intended to address human rights, local community impacts, and gender issues.

Two of the main characteristics of LTU's sustainability reporting show their commitment to SR:

i) The reporting is based on a multi-source sustainability framework. Thus, the 2011 Creating Futures Report is based on the GRI G3.1 Sustainability Reporting Guidelines, but the university's Communication on Progress is based on the United Nations Global Compact Principles (UNGCP). The reporting follows AccountAbility's (a private company devoted to aiding its customers in fulfilling objectives related to ethical, environmental, social, and governance accountability) AA1000 principles. Last, LTU has established its own targets and action lines in the 2010 Sustainability Report, titled Responsible Futures.

ii) The reporting aims to apply the framework at its highest levels. Thus, LTU applies the GRI G3.1 guidelines (at the A+ application level, the highest level in GRI reporting, with an external assessment) and the Advanced level of the UNGCP.

Another relevant feature of LTU's sustainability reporting is that it is designed to fulfil the more stringent requirements indicated in the recent literature on university SR, such as the guidelines established by the University Leaders for a Sustainable Future (ULSF, 
www.ulsf.org, which has advanced the well-known Talloires Declaration, 1990) and the GASU (Graphical Assessment of Sustainability in Universities) (Lozano, 2006). LTU's orientation towards advanced sustainability reporting is found within its second principle regarding sustainability (LTU, 2011: 3): integrating sustainability across all operations, curricula and research.

This principle facilitates LTU's efforts (within a 2020 horizon) in developing curricula on social and environmental sustainability issues. For 2012, LTU planned to "incorporate sustainability in the Graduate Certificate in Higher Education Curriculum Teaching and Learning”.

Research and service issues are also included within LTU's Sustainability Report 2011, as recommended by the ULSF and Lozano (2006). LTU's integrated approach to sustainability reporting is stated in its Creating Futures report (LTU 2012: 7):

"Our Sustainability Vision 2020 is informed by our Sustainability Principles and our belief that social, environmental and economic sustainability need to be integrated across everything we do and embedded in our daily work".

To develop that vision, LTU is focused on curriculum greening (e.g., implementing "curriculum on social and sustainability issues"), campus greening (through the reduction of water and energy consumption, as well as other policies), research on sustainability issues (through the creation of an active interdisciplinary network of researchers integrating business, public sector and non-government organisations), engagement and outreach (for instance, encouraging students to become sustainability leaders within the community through extracurricular activities).

\section{Discussion}

The adoption of the GRI reporting standards in universities remains low. Thus, it seems that the mere existence of the GRI reporting standards does not promote the systematic 
diffusion of SR (Mickwitz et al., 2008). Moreover, inconsistent SR has been observed, especially during early years of SR in universities. Thus, we have analysed the present data with a great amount of caution.

Hence, the findings indicate that the diffusion of SR among universities is slow and inconsistent in this beginning stage (Kemp and Volpi, 2008) because innovators may assume more risks and may not always obtain greater economic and non-economic benefit. Moreover, the process of diffusion regarding SR follows an S shape, as reported in previous research (see as example Barreto and Kemp, 2008, Nill, 2008, Marimon et al., 2012). The diffusion of SR is in an early expansion stage in the logistic curve, where more universities should adopt SR in the near future. Reinforcing this idea, Roger (1962) asserted that the first $2.5 \%$ of adopters can be considered innovators. In our case, the university sector has passed this threshold; therefore, it can be concluded that the university sector is in the early adopter stage. Today, university values related to both SD and SR are present in a sufficient number of university policies to conclude that the diffusion of SR in universities has passed the first stage of adoption; nevertheless, the phenomenon can still be considered an innovation. Our analysis supports Proposition 1 but not Proposition 2. Hence, these findings are consistent with previous research highlighting the evolution of the diffusion of SR in universities. Because of the low absolute numbers of certifications, any action taken by governments or organisations or any presently unidentified phenomenon that could affect the diffusion of the GRI reporting standards might change these forecasts significantly. Some authors have noted that the pressure of relevant stakeholders, such as students or faculty, could promote new efforts toward SR in universities (Fonseca et al., 2011; Yuan et al. 2013). Other authors, such as Carol and Petrella (2010), have suggested that providing GRI guidelines for universities would encourage more universities to take actions toward SD. Nevertheless, some internal barriers related to universities' governance structure, bureaucratic processes and data collection (Kemp and Volpi, 2008; Lozano et al., 2013) could hinder the adoption of SR in universities. 
This research also confirms findings from previous research focused on the diffusion of SR in specific geographical areas. Nill (2008) asserted that a mimetic effect could facilitate the adoption of the GRI reporting standards in areas where the diffusion of the GRI reporting standards is higher. Following this reasoning, the two main characteristics of the data gathered are the concentration of sustainability reports in the last few years represented in the table and the relatively vast number of sustainability reports from European universities. Furthermore, universities in Europe are more commonly adopting the GRI reporting standards compared with those in other geographical areas. Some universities are even publishing their sustainability reports yearly, but this practice is still uncommon among all universities. Commonly, universities provide a sustainability report in one year and then do not provide another report for several years. Thus, SR is inconsistent in universities worldwide. The pattern of SR in universities differs from the general pattern of SR identified by Marimon et al. (2012), in which Europe ranks first, Asia ranks second and Latin America ranks third. Therefore, Proposition 3 is only partially supported.

Only a few universities publish their sustainability reports under the GRI framework, and the two case study universities (LTU and EPFL) use different sustainability frameworks. LTU incorporates the GRI framework and the UN Global Compact Principles at the Advanced Level in its own framework for its 2010 SR and follows AccountAbility's AA 1000 Principles. EPFL, together with the GRI guidelines, applies the ISCN-GULF Sustainable Campus Charter. The application of several reporting frameworks is consistent with the findings of Lukman et al. (2009). Disterheft et al. (2012) noted that SR is an uncommon practice among universities. The use of different reporting frameworks is also consistent with the characterisation of sustainable development as an emergent paradigm in most universities (Lozano et al. 2013), because in the early stages of a paradigm's diffusion, a unique reporting framework may not exist. In addition, universities with more advanced SR attempt to apply reporting frameworks at their highest level. Thus, such universities aim to develop comprehensive reports, as noted by Alonso-Almeida et al. (2012), Lozano (2006), and Lozano et al. (2013). Both universities 
pursue SD in all dimensions in the proposed model. Thus, these cases provide some support for proposition 4 .

\section{Conclusions}

SD is a well-defined concept within higher education. Some HEIs have adopted SD principles, and their leaders are strongly committed to integrating SD principles into the missions of their institutions. HEIs can apply SD principles across four areas: curricula, research, campus, and outreach. HEIs apply SD principles across four areas: curricula, research, campus, and outreach. A sound SD vision requires clear reporting to inform the HEI stakeholders of the benefits of SD. However, while hundreds of universities in more than fifty countries have signed the Declaration of the "Higher Education Sustainability Initiative for Rio $+20 "$, only a small number of universities are reporting their sustainability efforts, and just a few of them are using the GRI framework.

Conclusions and trends can be derived from the findings of this study. A growing number of universities are involved in SR under the GRI guidelines, but the number of such universities is small considering the number of universities worldwide $(17,036$ universities and 21,250 HEIs in 2013, Cybermetrics Lab 2013). Hence, as noted, SD, and consequently SR, is in an early stage of adoption. Most likely, more stakeholder pressure will be required to increase the adoption of SR. Global problems, such as the on-going worldwide financial crisis, economic development, climate change and other sustainability-related issues, should be prioritized in universities' agendas as a way for them to achieve SD and benefit society.

European universities are pioneers in the adoption of the GRI reporting standards; thus, these universities can be considered innovators. Nevertheless, worldwide, universities are still in an early stage of adoption. Most of universities have not adopted the GRI reporting standards or other reporting standards related to $\mathrm{SD}$, but the general concern about $\mathrm{SR}$ is increasing, especially in young people, which might lead to greater adoption of reporting standards among 
HEIs. Other stakeholders are also pressuring universities to adopt reporting standards. Nevertheless, some action is needed to spread the knowledge of reporting standards and increase their adoption.

According to Adams and Petrella (2010), the collaboration between GRI, HEIs and other education stakeholders to produce a GRI sector supplement for universities would change the focus of education and make graduates ready for a changed world. Moreover, the GRI supplement for universities would drive an increase in the number of GRI reports.

As noted, future research should focus on SD practices in universities and their impact on universities and society. Universities are making efforts, in more or less intensity, toward SD, but these initiatives are reported in fragmented ways - such as on websites, in different reports or in university brochures - therefore, universities may be failing to exploit opportunities to improve their positioning compared with competitors. However, the adoption of SR standards can help to add value to all universities' sustainability initiatives and improve their visibility and reputation. Due to the reputation improvement derived from SR, universities could lever more funding, and attract better students and researchers.

For stakeholders, SR is a tool to compare SD activities among different universities and may aid in selecting the best universities for funding. Academic authorities should be provided with a better understanding of the benefits of adopting the GRI reporting standards to motivate them to adopt such standards. Thus, future research could investigate the motivation among universities for publishing GRI sustainability reports. Different criteria should be taken in account (i.e., organisational culture or having a signed declaration toward sustainability in the university). Nevertheless, adopting the GRI framework could be very useful for universities that aim to have a relevant social impact from sustainability reporting. Within universities, when sustainability managers use a set of widely acknowledged guidelines, they gain access to a growing network of sustainability reporters. Other benefits may be obtained by developers of sustainability reporting guidelines (including the GRI guidelines) when increasingly more 
universities adopt the GRI framework, because a large number of potential users is a powerful incentive for further the development of sustainability reporting guidelines.

This research has some limitations. First, the number of cases that were studied was limited. Future research must include a greater number of cases. Second, the quality of data in the GRI database is limited. In particular, considering that the reports are provided directly by the universities without a homogeneous control from the GRI, some university reports may have low reliability. We found at least one case in Spain in which a sustainability report was provided by a non-official source on behalf of the university. Lastly, considering that there are other SR frameworks different from GRI, it could be useful for future research to make a compared analysis of them. 


\section{List of acronyms}

CIC: Committee on International Cooperation

ENAC: (École)/Faculté de l'Environement Naturel, Architectural et Construit.

EPFL: École Polytechnique Fédérale de Laussane

GRI: Global Reporting Initiative

GULF: Global University Leaders Forum

GUNI: Global University Network for Innovation

HEI: Higher Education Institutions

ISCN: International Sustainable Campus Network

LTU: La Trobe University

SD: Sustainable Development

SR: Sustainability Reporting

STAUNCH: Sustainability Tool for Assessing Sustainability in UNiversities' Curricula Holistically

UN: United Nations

UNGCP: United Nations Global Compact Principles

WCED: World Commission on Environment and Development 


\section{References}

Adams, C., Heijltjes, M.G., Jack, G., Marjoribanks, T. Powell, M. (2011). The development of leaders able to respond to climate change and sustainability challenges: The role of business schools, Sustainability Accounting, Management and Policy Journal 2 (1), 165 171.

Adams, C., Petrella, L.(2010). Collaboration, connections and change: The UN Global Compact, the Global Reporting Initiative, Principles for Responsible Management Education and the Globally Responsible Leadership Initiative", Sustainability Accounting, Management and Policy Journal 1 (2), 292 - 296.

Alonso-Almeida, M., Marimon, F., Bernardo, M. 2013. Diffusion of quality standards in the hospitality sector, International Journal of Operations \& Production Management 33 (5): 504-527.

Alonso-Almeida, M.M., Llach, J., Marimon, F. (2012). A Closer Look at the 'Global Reporting Initiative' Sustainability Reporting as a Tool to Implement Environmental and Social Policies: A Worldwide Sector Analysis. Corporate Social Responsibility and Environmental Management DOI: 10.1002/csr.1318.

Arvidsson, K. (2004). Environmental management at Swedish universities. International Journal of Sustainability in Higher Education 5 (1), 91-99.

Barreto, L., Kemp, R. (2008). Inclusion of technology diffusion in energy-systems models: some gaps and needs. Journal of Cleaner Production, 16(1), S95-S101.

Barth, M., Adomßent, M., Albrecht, P., Burandt, S., Franz- Balsen, A., Godemann, J., Rieckmann, M. (2011). Towards a "Sustainable University“: scenarios for sustainable university development. International Journal of Innovation and Sustainable Development, 5(4), 313-332. DOI: 10.1504/IJISD.2011.043322.

Berman, J.E.,Webb, T., Fraser, D.J., Harvey, P.J., Barsky, J., Haider, A., 2003. Race to the Top: Attracting and Enabling Global Sustainable Business, Business Survey Report. World Bank Group, Washington, DC. 
Brown, H.S., de Jong, M., Levy, D.L. (2009). Building institutions based on information disclosure: lessons from GRI's sustainability reporting. Journal of Cleaner Production 17 (6), 571-580

Bryman, A. and Bell, E. (2007). Business Research Methods. $2^{\text {nd }}$ ed. Oxford: Oxford University Press.

Casadesus, M., Marimon, F., Alonso, M. (2010). The Future of Standardised Quality Management in Tourism: Evidence from the Spanish Tourist Sector. Service Industries Journal 30(14): 2457-74.

Church, R.L., Zimmerman, D.L., Bargerstock, B.A., Kenney, P.A. (2003). Measuring Scholarly Outreach at Michigan State University: Definition, Challenges, Tools. Journal of Higher Education Outreach and Engagement, Volume 8(1), Fall 2002/Winter 2003, 141-152.

CIC Committee on Engagement (2005): Engaged Scholarship: A Resource Guide. http://www.research2.ecu.edu/Documents/Carnegie/Engagement\%20Scholarship.pdf. Consulted May, 22th 2013.

Cybermetrics Lab (2013): World Ranking Web of Universities. www.webometrics.info.

Disterheft, A. Ferreira da Silva Caeiro, S. S., Ramos, M. R., de Miranda Azeiteiro, U.M. (2012). Environmental Management Systems (EMS) implementation processes and practices in European higher education institutions -Top-down versus participatory approaches. Journal of Cleaner Production 31, 80-90.

EPFL (École Polytechnique Fédérale de Lausanne) (2012): EPFL Sustainability Report 20102011. June 2012. Downloaded May 28, 2013 from http://developpementdurable.epfl.ch/page-82864-en.html.

Ferrer-Balas, D., Buckland, H., de Mingo, M. (2009). Explorations on the university's role in society for sustainable development through a systems transition approach. case-study of 
the technical university of catalonia (UPC). Journal of Cleaner Production 17(12), 10751085. doi:10.1016/j.jclepro.2008.11.006.

Filho, W. L. (2010). Teaching sustainable development at university level: Current trends and future needs. Journal of Baltic Science Education 9(4), 273-284.

Filho, W. L. (2011). About the role of universities and their contribution to sustainable development. Higher Education Policy, 24(4), 427-438. doi:10.1057/hep.2011.16

Fonseca, A., Macdonald, A., Dandy, E., Valenti, P. (2011) The state of sustainability reporting at Canadian universities. International Journal of Sustainability in Higher Education, 12 (1), 22 - 40

Franceschini, F., Galetto, M., Maisano, D., Mastrogiacomo, L. (2010). Clustering of European countries based on ISO 9000 certification diffusion. International Journal of Quality \& Reliability Management 27 (5), 558-575.

Gilbert, D.U., Rasche, A. (2007). Discourse ethics and social accountability: the ethics of SA 8000. Business Ethics Quarterly 17 (2), 187-216.

Global University Network for Innovation (GUNI) (2014). Higher Education in the World 5 Knowledge, Engagement and Higher Education: Contributing to Social Change. Series: GUNI Series on the Social Commitment of Universities. Hampshire: Palgrave Macmillan.

Global University Network for Innovation (GUNI), 2012. Higher Education in the World 4. Higher Education's Commitment to Sustainability: from Understanding to Action. Hampshire: Palgrave Macmillan.

Global University Network for Innovation (GUNI) (2008).Higher Education in the World 3. Higher Education: New Challenges and Emerging Roles for Human and Social Development. Series: GUNI Series on the Social Commitment of Universities. Hampshire: Palgrave Macmillan.

GRI. 2010. “Report List.” Accessed April 2011. http://www.globalreporting.org/ ReportServices/. 
Hassan M. (2001). Transition to sustainability in the twenty-first century: thecontribution of science and technology - Report of the World Conference of Scientific Academies held in Tokyo, Japan, 15-18 May 2000. International Journal of Sustainability in Higher Education 2(1):70-8.

Jickling, B., Wals, A.E.J. (2008): Globalization and environmental education: looking beyond sustainable development. Journal of Curriculum Studies 40(1), 1-21.

Kemp, R., Volpi, M. (2008). The diffusion of clean technologies: a review with suggestions for future diffusion analysis. Journal of Cleaner Production, 16(1), S14-S21.

Krajnc, D., Glavi, P., (2005). A model for integrated assessment of sustainable development. Resources, Conservation and Recycling 43, 189-208.

Larsen, H.N., Pettersen, J., Solli, C., Hertwich, E.G. (2013), Investigating the Carbon Footprint of a University - the case of NTNU. Journal of Cleaner Production, http://dx.doi.org/10.1016/j.jclepro.2013.03.034

Levy, D.L., Szejnwald Brown, H., de Jong, M. (2010). The Contested politics of corporate governance the case of the global reporting initiative. Business \& Society 49 (1), 88-115.

Llach, J., Marimon, F., Bernardo, M. (2011). ISO 9001 diffusion analysis according to activity sectors. Industrial Management \& Data Systems 111 (2), 298-316.

Lozano, R., et al., (2013) Advancing Higher Education for Sustainable Development: international insights and critical reflections, Journal of Cleaner Production http://dx.doi.org/10.1016/j.jclepro.2013.03.034

Lozano, R., Huisingh, D., (2011). Inter-linking issues and dimensions in sustainability reporting. Journal of Cleaner Production 19, 99-107.

Lozano, R., Watson, M. K. (2012). Chemistry Education for Sustainability: Assessing the chemistry curricula at Cardiff University. Educación Química, 24(2), 184-192,

Lozano, R., Young, W. (2013). Assessing sustainability in university curricula: exploring the influence of student numbers and course credits. Journal of Cleaner Production, $1-8$. 
Lozano, R. (2013). Sustainability inter-linkages in reporting vindicated: a study of European companies. Journal of Cleaner Production, 51, 57-65.

Lozano, R. (2011). The state of sustainability reporting in universities. International Journal of Sustainability in Higher Education 12(1), 67-78.

Lozano, R. (2010). Diffusion of sustainable development in universities' curricula: an empirical example from Cardiff University. Journal of Cleaner Production 18, 637-644.

LTU (La Trobe University) (2012): Creating Futures. Sustainability Report 2011.

Downloaded May 28, 2013 from http://www.latrobe.edu.au/sustainability/documents/4906_Creating_Futures_Web.pdf

Lukman, R., Krajnc, D., Glavic P. (2009). Fostering collaboration between universities regarding regional sustainability initiatives - the University of Maribor. Journal of Cleaner Production 17. 1143-1153.

Manetti, G. (2011). The quality of stakeholder Engagement in sustainability reporting: empirical evidence and critical points. Corporate Social Responsibility and Environmental Management 18, 110-122.

Marimon, F., Casadesús, M., Heras, I. (2010). Certification Intensity Level of the leading nations in ISO 9000 and ISO 14000 standards. International Journal of Quality \& Reliability Management 27 (9), 1002-20.

Marimon, F., Casadesús, M., Heras I. (2009). ISO 9000 and ISO 14000 standards: a projection model for the decline phase. Total Quality Management \& Business Excellence 20 (1), 1-21.

Marimon, F., Casadesús, M., Heras I. (2006). ISO 9000 and ISO 14000 standards: An international diffusion model. International Journal of Operations and Production Management 26(2), 141-65.

Marimon, F., Casadesus, M., Heras, I. (2004). A Dynamic Model for the Diffusion of ISO 9000 and ISO 14000 Standards. Proceedings of the International Conference on Modelling \& Simulation, Valladolid, Spain. 
Marimon, F., Llach, J., Bernardo, M. (2011). Comparative analysis of diffusion of the ISO 14001 standard by sector of activity. Journal of Cleaner Production 19(15): 1734-44.

Marimon, F., Alonso-Almeida, M., Rodríguez, M., Cortez A. (2012). The worldwide diffusion of the global reporting initiative: what is the point?. Journal of Cleaner Production 20(33), 132-144.

Matten D, Moon J. (2004). Corporate social responsibility education in Europe. Journal of Business Ethics, 54, 323-337.

Moneva Abadía J.M., Martín Vallespín, E, (2012). Universidad y desarrollo sostenible: análisis de la rendición de cuentas de las universidades públicas desde un enfoque de responsabilidad social. Revista Iberoamericana de Contabilidad de Gestión (RIGC) Vol. X, nº 19, Enero-Junio, 1-17.

Moore, T.L. Ward , K. (2008): Documenting Engagement: Faculty Perspectives on SelfRepresentation for Promotion and Tenure. Journal of Higher Education Outreach and Engagement, Volume 12, Number 4, pp 5-27.

Murga Menoyo, A. (2008). Perceptions, values and attitudes towards sustainable development. detection of educative needs of the students from university. Revista Espanola De Pedagogia, 66(240), 327-343.

Nill, J. (2008). Diffusion as time-dependent result of technological evolution, competition, and policies: the case of cleaner iron and steel technologies. Journal of Cleaner Production, 16(1), S58-S66.

Nilsson, J., Bjuggren, C., \& Frostell, B. (1998). Greening of a campus restaurant at stockholm university: Sustainable development audits by means of the SDR methodology. Journal of Environmental Management, 52(4), 307-315. doi:10.1006/jema.1997.0174 
Outtes Wanderley, L. S., Lucian, R., Farache, F., de Sousa Filho, J. M. (2008). CSR

Information Disclosure on the Web: A Context-Based Approach Analysing the Influence of Country of Origin and Industry Sector. Journal of Business Ethics, 82, 2, 369-378.

Perez-Batres, L.A., Miller, V.V., Pisan, J.P. (2010). CSR, sustainability and the meaning of global reporting for Latin American corporations. Journal of Business Ethics, 91, 193209.

Prado-Lorenzo, J.-M., Gallego-Alvarez, I. and Garcia-Sanchez, I. M. (2009), Stakeholder engagement and corporate social responsibility reporting: the ownership structure effect. Corporate Social Responsibility Environment Management, 16, 94-107.

Qi, G.Y., Zeng, S.X., Tam, C.M., Yin, H.T., Wuc, J.F., Dai, Z.H. (2011). Diffusion of ISO 14001 environmental management systems in China: rethinking on stakeholders' roles. Journal of Cleaner Production, 19(11), 1250-1256.

Rogers, E.M. (1962). Diffusion of Innovation. Free Press, NY.

Saadatian, O., Sopian ,K.B., Salleh, E. (2013): Adaptation of sustainability community indicators for Malaysian campuses as small cities. Sustainable Cities and Society, 6, pp. $40-50$.

Shriberg, M. (2002). Institutional assessment tools for sustainability in higher education. International Journal of Sustainability in Higher Education 3(3), 254-270.

Scott, J. (1990). A Matter of Record. Documentary Sources in Social Research. Cambridge: Polity Press.

Tsang, S., Welford, R., Brown, M. (2009). Reporting on community investment. Corporate Social Responsibility and Environmental Management 16, 123-136.

Waas, T., Hugé, J., Ceulemans, K., Lambrechts, W., Vandenabeele, J., Lozano, R., Wright, T. (2012) Sustainable Higher Education - Understanding and Moving Forward. Flemish Government - Environment, Nature and Energy Department, Brussels. 
Wals, A.E.J. (2013). Sustainability in higher education in the context of the UN DESD: are view of learning and institutionalization processes. Journal of Cleaner Production, in press. doi:http://dx.doi.org/10.1016/j.jclepro

Waples, E. P., Antes, A. L., Murphy, S. T., Connelly, S., Mumford, M. D. (2008). A Meta-Analytic Investigation of Business Ethics Instruction. Journal of Business Ethics, 87(1), 133-151.

World Commission on Environment and Development WCED (1987). Our Common Future, http://conspect.nl/pdf/Our Common FutureBrundtland Report 1987.pdf. Accessed May 2013.

Wright, T. S.A. (2004): The revolution of sustainability declarations in Higher education. In Peter Blaze Corcoran \& Arjen E.J. Wals (Eds.), Higher Education and the Challenge of Sustainability: Problematics, Promise and Practice, 7-19. Kluwer Academic Publishers. Printed in the, Netherlands.

Wright, T.S.A., Wilton, H. (2012). Facilities management directors' conceptualizations of sustainabilityin higher education. Journal of Cleaner Production 31, pp. 118 -125.

Yarime, M., Trencher, G., Mino, T., Scholz, R., Olsson, L., Ness, B., Frantzeskaki, Ni., \& Rotmans, J. (2012). Establishing sustainability science in higher education institutions: towards an integration of academic development, institutionalization, and stakeholder collaborations. Sustainability Science, 7(0), 101-113. doi: 10.1007/s11625-012-0157-5

Yuan X., Zuo, J. Huisingh, D. (2013). Green Universities in China e what matters?. Journal of Cleaner Production, http://x.doi.org/10.1016/j.jclepro.2012.12.030. 
Figure 1. Sustainable development in universities model.

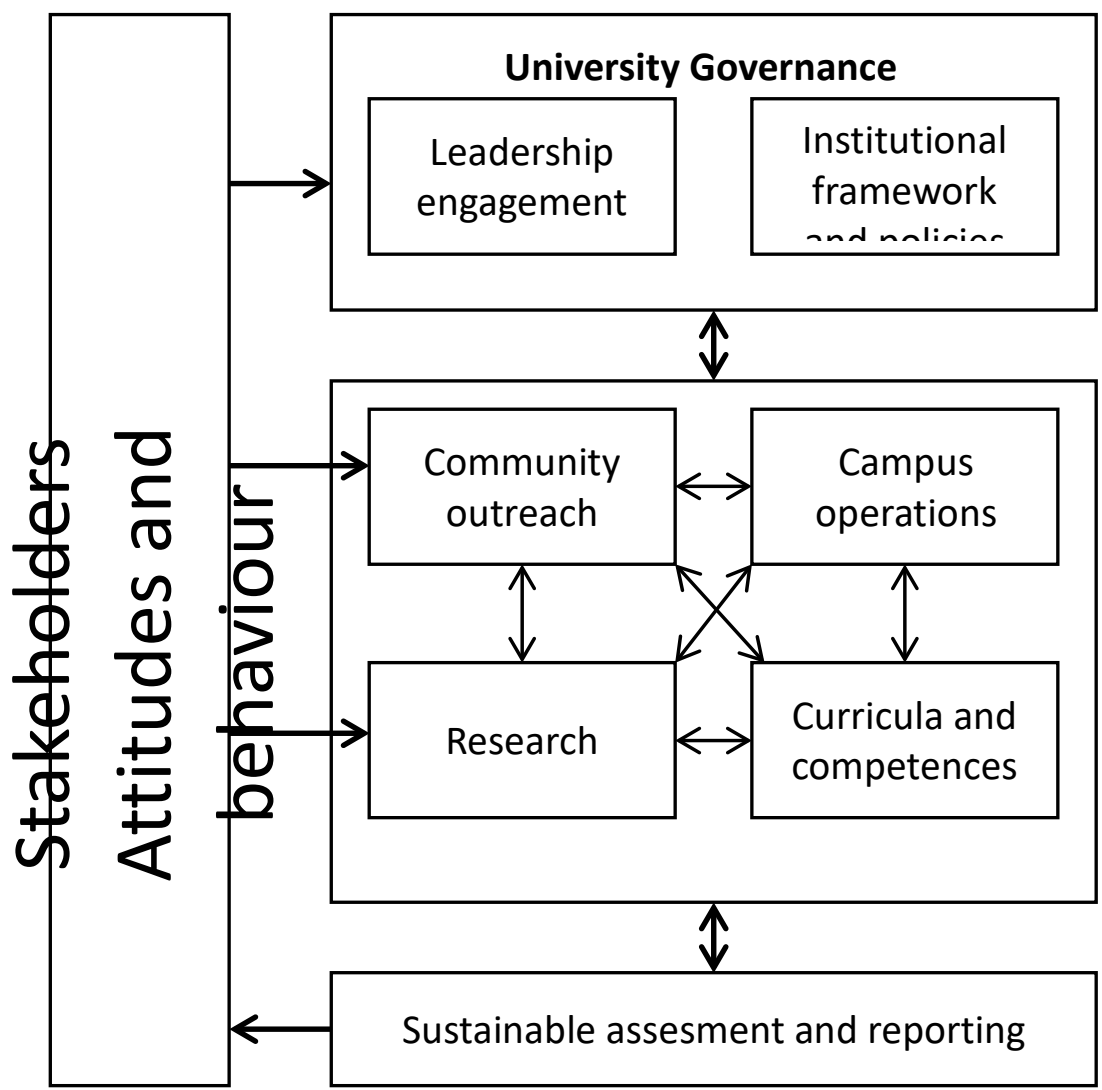

Source: Adapted from Lozano, 2006 and Lozano et al. (2013). 
Figure 2. GRI evolution and forecast for public industries displaying the logistic curve pattern. 
Non Profit Services

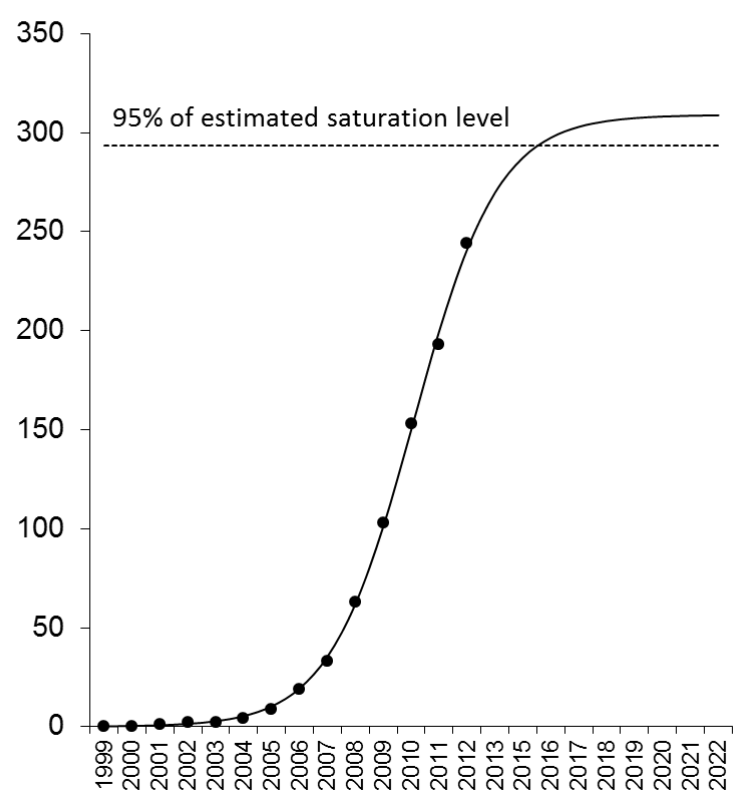

Public Agency

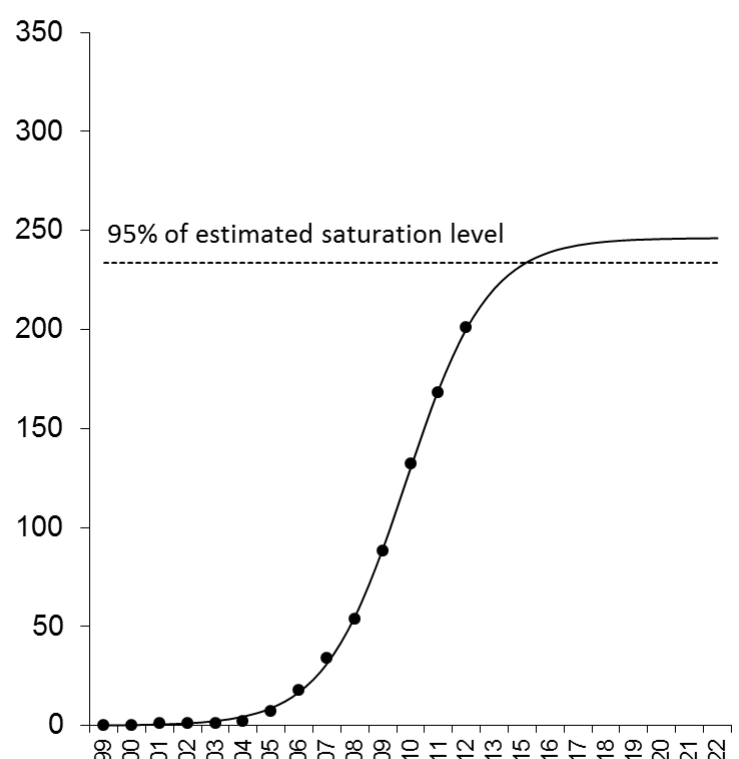

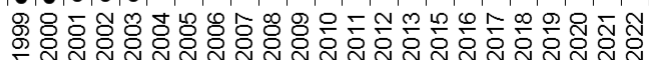


Healthcare Services

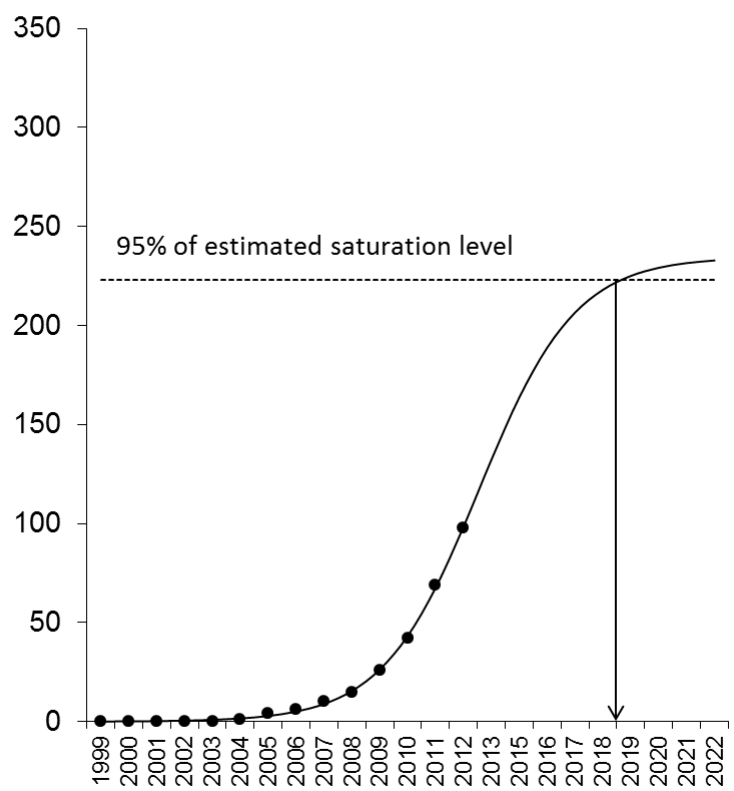

\begin{tabular}{|c|c|c|c|c|c|c|c|c|c|}
\hline & \multicolumn{3}{|c|}{ Non Profit Services } & \multicolumn{3}{|c|}{ Public Agencies } & \multicolumn{3}{|c|}{ Healthcare Services } \\
\hline & Value & $\mathbf{L l}^{\mathbf{a}}$ & $\mathbf{U l}^{\mathrm{b}}$ & Value & $\mathbf{L l}^{\mathbf{a}^{\mathrm{a}}}$ & $\mathbf{U l}^{\mathrm{b}}$ & Value & $\mathbf{L l}^{\mathbf{a}}$ & $\mathbf{U l}^{\mathrm{b}}$ \\
\hline $\mathbf{N}_{0}$ & 0.20 & .09 & 0.31 & 0.15 & 0.10 & 0.21 & .09 & .04 & 0.14 \\
\hline $\mathbf{K}$ & 308.99 & 284.25 & 333.74 & 246.25 & 233.81 & 258.69 & 234.65 & 170.02 & 299.29 \\
\hline $\mathbf{r}_{0}$ & .66 & .60 & .72 & .68 & .64 & .72 & .58 & .53 & 0.63 \\
\hline r squared & & .999 & & & 1.000 & & & 0.999 & \\
\hline
\end{tabular}

${ }^{a}$ the lower limit of the 95 percent confidence interval ${ }^{b}$ the upper limit of the 95 percent confidence interval 
Figure 3. GRI evolution and forecast for universities exhibiting the logistic curve pattern.

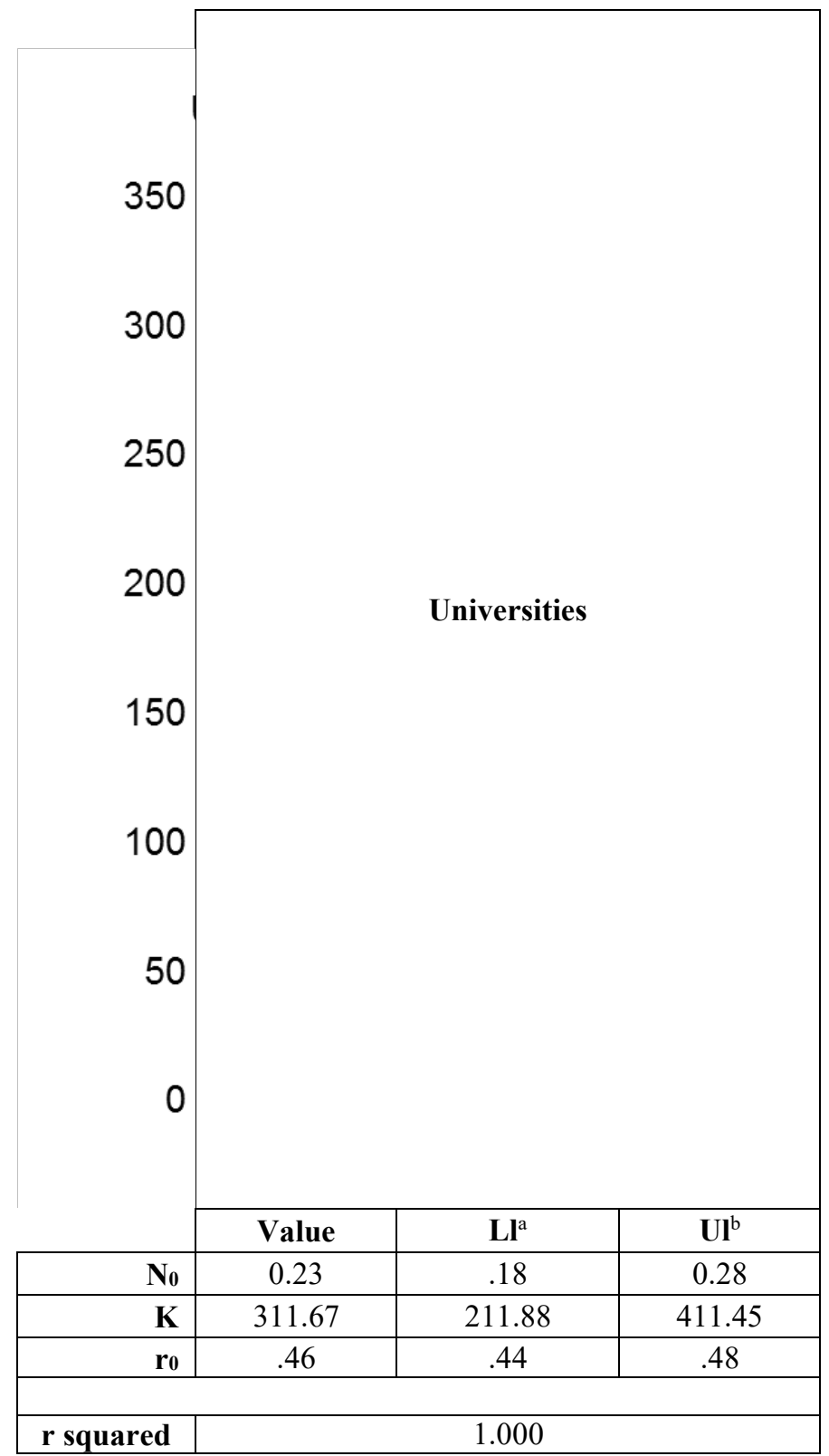

${ }^{\text {at }}$ the lower limit of the 95 percent confidence interval

bthe upper limit of the 95 percent confidence interval 